\section{Intracellular Thioctic Acid and Coenzyme A following Vanadium Treatment}

IT was suggested in a previous communication ${ }^{1}$ that the fall in coenzyme A liver concentrations in animals treated with vanadium might be due, at least partially, to a reduction in the number of $-\mathrm{SH}$ groups available. This hypothesis was based on the following facts: (1) The toxic effects of vanadium may, to a great extent, be attributed to modifications in reactions connected with sulphur compounds, especially those of the thiolic type ${ }^{2}$. (2) The lack of - SH groups, and particularly of sulphurated aminoacids, lowers the coenzyme $\mathrm{A}$ content in the liver ${ }^{3}$; in this case, a fall in thioctic acid, the connexion of which with coenzyme $\mathrm{A}$ is well-known, also occurs in the tissues ${ }^{4}$.

These investigations were undertaken on the basis of the above considerations to assess the effects of vanadium treatment on the liver content and intracellular distribution of thioctic acid and coenzyme A.

The experiments were performed on rats bred by us, of average weight $120-150 \mathrm{gm}$., fed on a diet of known composition ${ }^{1}$ starting 7 days after the beginning of the experiment. Vanadium was administered mixed with their diet, at the level of 0.05 per cent, in the form of sodium metavanadate $\left(\mathrm{NaVO}_{3} \cdot 4 \mathrm{H}_{2} \mathrm{O}\right)$ for 14 days. At the end of this period, the animals were killed by bleeding, and their livers removed for analysis.

Some analyses were carried out on the whole liver homogenate, and some on fractions obtained by centrifugation at 500 r.p.m. (nuclei), 3,000 r.p.m. (mitochondria) and 20,000 r.p.m. (microsome particles), in accordance with the standard procedure.

The following determinations were then made: coenzyme $\mathrm{A}^{5}$; thioctic acid ${ }^{6}$; and proteins ${ }^{7}$. The results are given in Table 1 .

In the whole homogenate more thioctic acid dis appeared than coenzyme $\mathrm{A}$; the sharpest reduction occurred in the mitochondrial fraction, where thioctic acid and coenzyme A were respectively 86 and 52.5 per cent below normal ; in the remaining homogenate fractions, variations in both thioctic acid and coenzyme A, were far less marked than those observed in mitochondria.

These results would suggest a slow-down in the biosynthesis of coenzyme A, caused, at least in part, by the non-decarboxylation of pantothenylcysteine to pantotheine, which process is known to require pyridoxal phosphate as the prosthetic group : indeed, vanadium would seem to affect this reaction ${ }^{8}$.

The fall of thioctic acid concentrations in the tissues might be regarded partly as a clue to a more widespread alteration in the metabolism of sulphurated substances, and partly as the result of the lack of coenzyme A, which is essential for restoring the dithiolic form of the lipothiamide.

In other words, the fall in coenzyme A concentrations in the livers of animals treated with vanadium might be the result of two different actions exerted (1) on pyridoxal-phosphate and, (2) on the metabolism

\begin{tabular}{|c|c|c|c|c|}
\hline $\begin{array}{c}\text { Fomogenate } \\
\text { Fraction }\end{array}$ & \multicolumn{4}{|c|}{$\begin{array}{l}\text { I ANIMALS TREATED WITH VANADIUM (AVERAGH } \\
\text { VALUES } \pm \text { S.E.) }\end{array}$} \\
\hline $\begin{array}{c}\text { Homogenate } \\
\text { Fraction }\end{array}$ & $\begin{array}{c}\text { Thioctic } \\
\text { Acid : } \\
\text { control }(8)^{*}\end{array}$ & $\begin{array}{c}\mu \mathrm{gm} . / \mathrm{gm} . \\
\text { Protein : } \\
\text { treated (10) }\end{array}$ & $\begin{array}{c}\text { Cocnzyme } \\
\text { A : } \\
\text { control (8) }\end{array}$ & $\begin{array}{l}\text { U/100 mgm. } \\
\text { Protein : } \\
\text { treated (10) }\end{array}$ \\
\hline Whole & $8 \cdot 33 \pm 0 \cdot 39$ & $2.37 \pm 0.18$ & $91 \cdot 6$ & 50 \\
\hline Mitochondria & $29 \cdot 37 \pm 1 \cdot 64$ & $4 \cdot 16 \pm 0 \cdot 25$ & $260 \cdot 6 \pm 11 \cdot 5$ & $124 \cdot 1 \pm 8 \cdot 6$ \\
\hline $\begin{array}{l}\text { Nuclei } \\
\text { Microsme }\end{array}$ & $4 \cdot 98 \pm 0 \cdot 18$ & $3 \cdot 58 \pm 0 \cdot 20$ & $67.1 \pm 3.1$ & $59 \cdot 8 \pm 5 \cdot 0$ \\
\hline Supernatant & $4 \cdot 57 \pm 0 \cdot 21$ & $2 \cdot 44+0 \cdot 13$ & $51 \cdot 8 \pm 2 \cdot 4$ & $35 \cdot 4 \pm 2 \cdot 7$ \\
\hline
\end{tabular}

* Number of animals given in brackets. of sulphurated substances. This would appear to be confirmed by the preliminary results of investigations now being performed in this Laboratory ; treatment with pantothenic acid and/or cysteine causes only a slight increase of coenzyme $\mathbf{A}$ concentrations in the liver of rats kept on a diet supplemented with vana. dium, so a substantial degree of protection appears to be provided by pantotheine.

\section{E. Mascitelli-Coriandoli C. Crtterio}

Research Department,

Farmavigor S.p.A.,

Milano.

Aug. 10

1 Mascitelli-Coriandoli, $\mathrm{k}$., and Citterio, C., Nature, 183, 1527 (1959). 2 Mountain, J. T., Delker, L. L., and Stokinger, H. E., Amer. Med 4ssoc. Arch. Indust. Hyg., 8, 406 (1953). Snyder, F., and Cornatzer, W. E., Nature, 182, 462 (1958)

Dunning, J. S., Neatrom, R., and Day, P. L., $J$. Nutr., 56, 431 (1955). Wenneker, A. S., and Recant, $L_{0,}$ ibid., 64, 127 (1958)

作, (1952) i Fischer, G. L., ibid., 90, 153 (1955).

${ }_{6}^{5}$ Kaplan, N. O., and Lipmann, F., $J$. Biol. Chem., 174, 37 (1948). Hawk, P. B., Oser, B. L., and Summerson, W. H, 'Practical Physio-

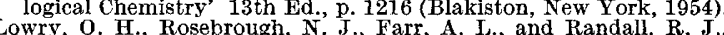
J. Biol. Chem., 193, 265 (1951).

${ }^{8}$ Boeri, E., and Ehrenberg, A., Arch. Biochem. Biophys., 50, 404 (1954). Underwood, E. J., 'Trace Elements in Human and Animal Nutrition', p. 385 "'Academic Press, New York, 1956). Bergel, F., Bray, R. C., and Harrap, K. R., Nature, 181, 1654 (1958).

\section{Deaminases of Adenylic Acid and Adenosine in Rat Kidney}

Hitherto it has been generally accepted that only muscle, blood and nervous tissue contain a specific adenylic deaminase ${ }^{1,2}$. Recently, however, we have succeeded in separating adenylic deaminase from adenosine deaminase by using rat kidneys.

Rat kidney homogenate prepared in $0 \cdot 1 M$ potassium chloride containing $0.039 M$ borate buffer $p H \quad 7$, produced both ammonia and inorganic phosphate when incubated with muscle adenylic acid. When the homogenate was fractionated by differential centrifugation, the phosphatase activity was localized mainly in the mitochondrial fraction (sedimenting between 3,000 and $16,000 \mathrm{~g}$ ). This fraction, however, was practically devoid of deaminase activity (Table 1). After the centrifugation of the mitochondrial fraction there remained a clear reddish liquid (cytoplasm). When dialysed against distilled water at $0^{\circ} \mathrm{C}$. for $24 \mathrm{hr}$., the cytoplasm separated into a water-insoluble fraction (cytoplasmic globulins) and a water-soluble Table 1. Deamination AND Dephosphonylation OF ADENyliC

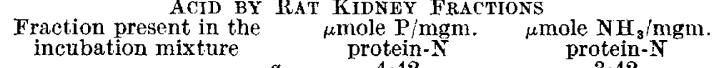

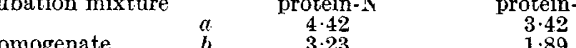
$\begin{array}{llll} & a & 4 \cdot 42 & 3 \cdot 42 \\ \text { Whole homogenate } & b & 3.23 & \mathbf{1} 89 \\ & c & 3.98 & \mathbf{2}\end{array}$ $\begin{array}{lrrr} & c & 3 \cdot 98 & 2 \cdot 58 \\ \text { Mitochondrial fraction } & a & 14.70 & 1 \cdot 71 \\ & b & 7.23 & 0.0\end{array}$ $\begin{array}{rrrr}c & 8.85 & 0.80 \\ & a & 1.40 & 2.68\end{array}$ $\begin{array}{llll}\text { Cytoplasmic albumins } & a & 1 \cdot 40 & 0 \\ & c & 1.33 & 0 \cdot 56 \\ & c & 1.05 & 1.11\end{array}$ $\begin{array}{llll} & a & 1.21 & \mathbf{5} \cdot 65 \\ \text { Cytoplasmic globulins } & b & \mathbf{1 . 4 3} & \mathbf{5 \cdot 4 5}\end{array}$ Rat kidneys were homogenized in 7.5 vol. of $0.1 \quad \stackrel{M}{M}$ potassium chloride containing $39 \mathrm{mM}$ borate buffer $p \mathrm{H} 7$, the homogenate centrifuged at $3000 \mathrm{~g}$ for $10 \mathrm{~min}$., and the sediment disregarded. The supernatant was centrifuged at $16000 g$ for $15 \mathrm{~min}$. The sediment thus obtained is called the "mitochondrial fraction'. The clear supernatant solution was further separated in two fractions by dialysis against distiled water for $24 \mathrm{hr}$; : the water-soluble, "cytoplasmic albumins and the water-insoluble، $a, b, c$, indicate different animals

The incubation mixtures contained $0.025 M$ succinate buffer $p H 6$, $0.005 M$ adenylic acid, $0 \cdot 1 M$ potassium chloride and the appropriate $25^{\circ} \mathrm{C}$. by the addition of trichloroacetic acid to the final concentration of 7.5 per cent. In the filtrates inorganic phosphate was estimated by the method of Gomori (ref. 3) and ammonia according to Russel (ref. 4 ) by Conway's microdiffusion method. The results, each representing an average from two samples obtained from one animal, were expressed in terms of $\mu$ moles $/ \mathrm{mgm}$. protein-nitrogen. 